\title{
Infiltration, seepage and slope instability mechanisms during the 20-21 November 2000 rainstorm in Tuscany, central Italy
}

\author{
V. Tofani ${ }^{1}$, S. Dapporto ${ }^{2}$, P. Vannocci ${ }^{1}$, and N. Casagli ${ }^{1}$ \\ ${ }^{1}$ Earth Sciences Department, University of Florence, Italy \\ ${ }^{2}$ Regione Toscana, Sistema Regionale di Protezione Civile, Italy
}

Received: 23 November 2005 - Revised: 20 November 2006 - Accepted: 20 November 2006 - Published: 12 December 2006

\begin{abstract}
On 20-21 November 2000, a storm of high intensity, with a estimated return period of more than 100 years, triggered over 50 landslides within the province of Pistoia in Tuscany (Italy). These failures can be defined as complex earth slides- earth flows. One of the documented landslides has been investigated by modelling the ground water infiltration process, the positive and negative pore water pressure variations and the effects of these variations on slope stability during the rainfall event. Morphometric and geotechnical analyses were carried out through a series of in-situ and laboratory tests, the results of which were used as input for the modelling process. The surface infiltration rate was initially simulated using the rainfall recorded at the nearest raingauge station. Finite element seepage analysis for transient conditions were then employed to model the changes in pore water pressure during the storm event, using the computed infiltration rate as the ground surface boundary condition. Finally, the limit equilibrium slope stability method was applied to calculate the variations in the factor of safety during the event and thereby determine the critical time of instability. For the investigated site the trend of the factor of safety indicates that the critical time for failure occurs about $18 \mathrm{~h}$ after the storm commences, and highlights the key role played by the soil permeability and thickness in controlling the response in terms of slope instability.
\end{abstract}

\section{Introduction}

Rainfall is considered the most frequent landslide-triggering factor in many regions of the world (Corominas, 2001). "A triggering factor is an external stimulus such as intense rainfall, earthquake shaking, volcanic eruption, a storm wave or rapid stream erosion that causes a near-immediate response

Correspondence to: V. Tofani

(veronica.tofani@geo.unifi.it) in the form of a landslide by rapidly increasing the stresses or reducing the strength of slope materials" (Wieczorek, 1996). Triggering by rainfall can be defined as a decrease in shear strength due to an increase in pore water pressure on the potential failure surface which finally results in a slope failure (Terlien, 1998). The frequency and magnitude of rainfall events, together with other factors such as lithology, morphology and land cover, influence the type of landslide (Van Ash et al., 1999; Crosta, 1998). Generally, deep-seated landslides are often triggered by moderate intensity rainfall distributed over long periods whereas superficial landslides such as soil slips and debris flows are triggered by short duration, intense precipitation (Corominas, 2001). During intense rainfall events the variations in pore water pressures distributed within the soil are highly variable depending on the hydraulic conductivity, topography, degree of weathering, and fracturing of the soil. Pore water pressure increases may be directly related to rainfall infiltration and percolation or may be the result of the build-up of a perched or groundwater table (Terlien, 1998). The response of the material involved is largely dependent on its permeability. In high-permeability soils the build-up and dissipation of positive pore pressures during intense precipitation events could be very rapid (Johnson and Sitar, 1990). In these cases slope failures are caused by high intensity rainfall and antecedent rainfall has little influence on landslide occurrence (Corominas, 2001). On the contrary, in low-permeability soils slope failures are caused by long duration-moderate intensity rainfall events; in fact, the reduction in soil suction and the increase in pore water pressures due to antecedent rainfall is considered a necessary condition for landslide occurrence (Sanderson et al., 1996; Wieczorek, 1987).

On the basis of a statistical analysis of landslide events and rainfall characteristics, critical rainfall amounts that have triggered landslides can be estimated (e.g. Caine, 1980; Govi and Sorzana, 1980; Cannon and Allen, 1985; Crozier, 1986; Kim et al., 1991; Terlien, 1996, 1998; Pasuto and Silvano,

Published by Copernicus GmbH on behalf of the European Geosciences Union. 
1998; Glade et al., 2000; Sidle and Dhakal, 2002; Jakob and Weatherly, 2003; Ko Ko et al., 2004). When a statistical analysis is impossible due to the lack of data, the hydrological hillslope processes have to be investigated in order to explain the triggering mechanisms of the landslides (e.g. Anderson and Howes, 1985; Brooks and Richards, 1994; Crosta, 1998; Iverson, 2000; Crosta and Del Negro, 2003)

Hydrological physically-based models have been commonly used to simulate saturated and unsaturated flow in natural slopes. Several hydrological models can be directly linked to slope stability models to enable accurate simulations of the plausible stability conditions. Examples of hydrological-stability models are CHASM (Anderson and Lloyd, 1991), HYSWASOR (Van Genuchten, 1980), HILLFLOW (Bronstert, 1994) or GWFLUCT v 2.0 (Terlien, 1996). The GEO-Slope package is another example of a coupled hydrological-slope stability model within which SEEP/W (Geo-Slope, 2003a) analyses the seepage problems and SLOPE/W (Geo-Slope, 2003b) performs the slope stability analysis adopting the limit equilibrium method. Coupled SEEP/W-SLOPE/W analyses have been used to evaluate the dynamic conditions of both the stability of riverbanks (Affuso et al., 2000; Rinaldi et al., 2004) and slopes (Crosta and Dal Negro, 2003; Aleotti et al., 2004; Collins and Znidarcis, 2004; Casagli et al., 2005).

In this study the mechanism behind rainfall-triggered landslides is modelled by using combined infiltration, seepage and stability analyses. This method allows the evaluation of the terrain and its response based on geological, physical, hydrogeological and mechanical characteristics. The main objective was to investigate the instability mechanisms behind rainfall-triggered landslides that occurred during the storm of 20-21 November 2000 in Tuscany. Two such landslides have been analyzed in Casagli et al. (2005) and this paper presents a third case study, Collodi landslide, using the same approach of a general infiltration analysis combined with a hydrological-slope stability analysis performed with the software SEEP/W and SLOPE/W (Geo-Slope, 2003a, b).

\section{Study area and rainfall event}

The study area is located in the NW portion of the province of Pistoia, in Tuscany, Italy, and includes the municipalities of Montecatini Terme, Pescia, Massa e Cozzile and Uzzano. The local topography is characterised by elevations ranging from $20 \mathrm{~m}$ a.s.l. to about $950 \mathrm{~m}$ a.s.l. (Fig. 1) and slope gradients varying from $0^{\circ}$ in the plain and $55^{\circ}$. The predominant rock type in the study area is a flysch formation (Macigno), composed of quartz and feldspar sandstone alternated with layers of siltstone. In the mid and upper sections of the valley, where most landslides occurred, the stratigraphy consists of a 1.5 to $5 \mathrm{~m}$ thick layer of colluvial soil overlying the bedrock.
The annual precipitation recorded from 1970 to 2000 at the two raingauge stations located in the study area, Marliana and Pescia, has a bimodal monthly distribution with maxima in November (mean rainfall $168.4 \mathrm{~mm}$ in Marliana and $164.71 \mathrm{~mm}$ in Pescia) and January (mean rainfall $135.4 \mathrm{~mm}$ in Marliana and $128.4 \mathrm{~mm}$ in Pescia). July is the driest month with a mean precipitation not exceeding $38 \mathrm{~mm}$ for both stations (Fig. 2). Mean annual rainfall increases with relief, ranging from $1100 \mathrm{~mm}$ in the lower valley to about $1800 \mathrm{~mm}$ at higher elevations.

On 20-21 November 2000, a cyclonic storm precipitated about 200 to $220 \mathrm{~mm}$ of rainfall over a period of $38-40 \mathrm{~h}$. The rainfall recorded at the two raingauge stations, Marliana and Pescia, ,reached a maximum intensity of about $17 \mathrm{~mm} / \mathrm{h}$. These conditions give the event an estimated return period of over 100 years, using the Gumbel distribution method on the rainfall record for the last 30 years (Tofani, 2003). Intensive antecedent rainfall was also recorded over the three weeks prior to the event giving a total of 587 and $522 \mathrm{~mm}$ of precipitation for November 2000, respectively in Marliana and Pescia stations, which is the highest amount recorded since 1970, exceeding the monthly average by $328 \%$ (Fig. 2) (Casagli et al., 2005).

This storm triggered over 50 landslides in the study area and the majority of the mass movements were complex landslides that initiated as slides and evolved into flows, some were purely slides and only few movements were falls.

The following sections detail the site morphometry, submodels and their parameterization, focusing in particular on the Collodi landslide. The applied analysis is identical in concept to the analyses carried out on Massa e Cozzile and Uzzano landslides, described in a previous paper by Casagli et al. (2005).

\section{Morphometry and characterisation of soil properties}

Collodi landslide is a complex earth slide-earth flow (Cruden and Varnes, 1996). The landslide developed from an elevation of about $200 \mathrm{~m}$ a.s.l. and reached an elevation of $179 \mathrm{~m}$ a.s.l., the total length was $60 \mathrm{~m}$ and the maximum width was about $20 \mathrm{~m}$. In this area the thickness of the colluvial soil, where the landslide occurred, ranges between 1 and $2 \mathrm{~m}$ and the main scarp has a depth of $1-1.5 \mathrm{~m}$. The topography of the landslide site was determined by means of a differential GPS survey of the pre- and post-failure slope profiles. The pre-failure profile was obtained by averaging the undisturbed profiles surveyed on both sides of the landslide body following the rainfall event.

Soil geotechnical parameters were determined from a series of in-situ and laboratory tests. The in-situ tests included the Borehole Shear Test (Lutenegger and Halberg, 1981; Dapporto et al., 2000) which obtains shear strength parameters under natural conditions without disturbing the soil samples, matric suction measurements with a tensiometer, 


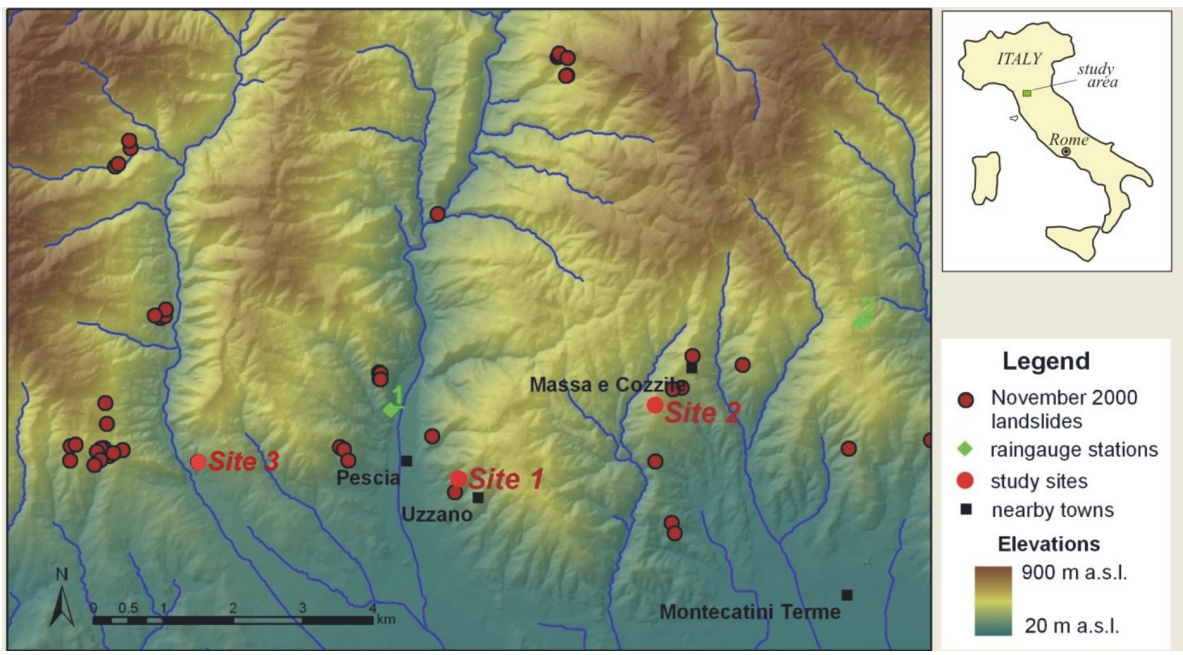

Fig. 1. Map of the study area with locations of November 2000 landslides, raingauge stations (1 Pescia, 2 Marliana), study sites (Site 1, Uzzano, Site 2, Massa e Cozzile, Site 3 Collodi) and nearby towns.

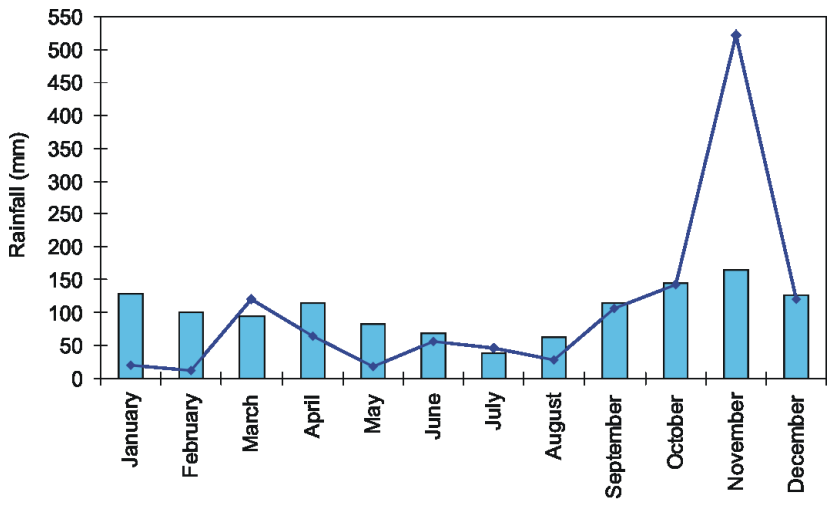

Fig. 2. Precipitation recorded in Pescia raingauge station, with bars the mean monthly precipitation from 1970 to 2000, with the line the monthly precipitation in 2000 .

and a constant head permeameter test performed with an Amoozemeter (Amoozegar, 1989). Additionally, a series of laboratory tests were conducted, including the determination of grain size distribution and Atterberg limits, the phase relationship analysis and the direct shear test.

Collodi soil can be classified as a silty sand (SM) according to the Unified Soil Classification System (Wagner, 1957) with a porosity (n) of $44 \%$ and a saturated unit weight $(\gamma)$ of $19 \mathrm{kN} / \mathrm{m}^{3}$. A shear strength angle $\left(\phi^{\prime}\right)$ of $35^{\circ}$ and an effective cohesion $\left(c^{\prime}\right)$ of $0 \mathrm{kPa}$ was obtained from the direct shear test (Fig. 3).

BST measurements were carried out in the unsaturated portion of the soil where the pore water pressure $u_{w}$ is lower with respect to the air pressure $u_{a}$. The difference between the two parameters $\left(u_{a}-u_{w}\right)$ is the soil matric suction. The presence of the matric suction in unsaturated soils increases

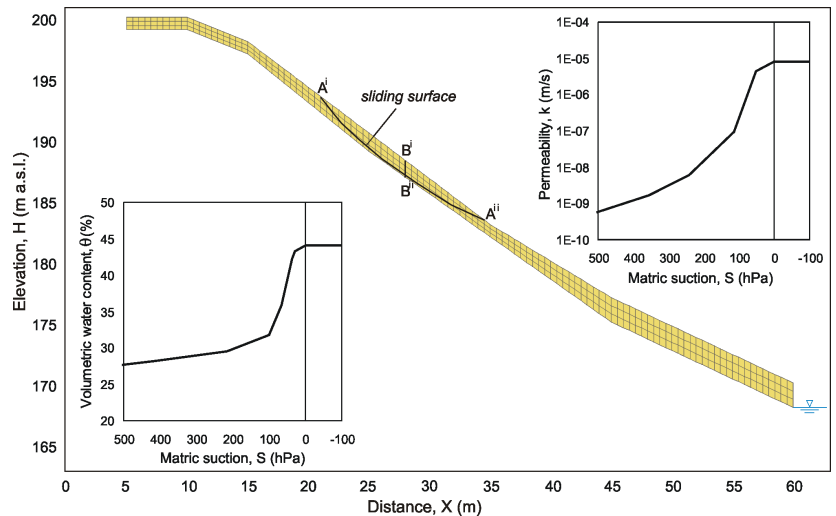

Fig. 3. Finite element description of slope geometry, soil water characteristic curve and K-curve for Collodi site.

their shear strength. However, an increase in pore water pressures and consequently a decrease in matric suction can reduce the soil shear strength and lead to slope failure.

For an unsaturated soil the failure criterion is expressed in terms of two stress state variables, the net normal stress $(\sigma-$ $u_{a}$ ) and the matric suction $\left(u_{a}-u_{w}\right)$, in the following form proposed by Fredlund et al. (1978):

$\tau=c^{\prime}+\left(\sigma-u_{a}\right) \tan \phi^{\prime}+\left(u_{a}-u_{w}\right) \tan \phi^{b}$

where $\tau$ is the shear strength, $c^{\prime}$ is effective cohesion, $\sigma$ is the total normal stress, $u_{a}$ is the pore air pressure, $\phi^{\prime}$ is effective friction angle, $u_{w}$ is the pore water pressure, $\phi^{b}$ is the angle expressing the rate of increase in strength relative to the matric suction $\left(u_{a}-u_{w}\right)$.

Equation (1) represents an extension of the traditional Mohr-Coulomb failure criterion in terms of effective stress because, as the soil approaches the saturation, $u_{a}$ becomes 
equal to $u_{w}$ and the component related to the matric suction disappears.

The BST results provided a linear relationship between the net normal stress $\left(\sigma-u_{a}\right)$ and the shear strength $\tau$. Interpreting the results in terms of the Fredlund et al. (1978) criterion the horizontal projection of the shear strength $(\tau)$ vs. the ( $\sigma-$ $u_{a}$ ) plane, for a given matric suction, results in a line with the equation:

$\tau=c+\left(\sigma-u_{a}\right) \tan \phi^{\prime}$

where $c$ represents the total cohesion that results from the sum of the effective cohesion and the apparent cohesion due to the effect of the matric suction:

$c=c^{\prime}+\left(u_{a}-u_{w}\right) \tan \phi^{b}$

For the Collodi soil it was possible to separate the apparent cohesion component by subtracting the effective cohesion determined with the direct shear test from the total cohesion. Furthermore, the measurement of the matric suction $\left(u_{a}-u_{w}\right)$ by a tensiometer during the test also allowed the estimation of the $\phi^{b}$ angle using:

$\phi^{b}=\arctan \left[\left(c-c^{\prime}\right) /\left(u_{a}-u_{w}\right)\right]$

The BSTs and the direct shear test provided similar results for the effective shear strength angle while the measured cohesion was higher in BSTs due to the contribution of matric suctions.

The saturated permeability $\left(k_{s}\right)$ was estimated performing Amoozemeter (also called Compact Constant Head Permeameter) tests within the unsaturated zone of the soil. The representative $k_{s}$ value of the entire Collodi soil layer was around $8 \times 10^{-6} \mathrm{~m} / \mathrm{s}$ (Fig. 3).

\section{Infiltration analysis}

The infiltration rate at the surface during the rainstorm was predicted by using a modified Chu (1978) approach for the Green and Ampt (1911) equations in the case of unsteady rainfall. The Green-Ampt approach, based on Darcy's law, was intended to be used where infiltration results from a permanent excess of water at the ground surface. In fact, in the original form proposed by Green and Ampt it is assumed that the soil surface is covered by ponded water of negligible depth and that the water infiltrates into a deep homogeneous soil with a uniform initial water content. Water is assumed to enter the soil, in order to define a distinct wetting front separating the wet and dry regions. The equation of the GreenAmpt model is:

$f_{p}=\frac{K_{S}(L+S)}{L}$

Where $f_{p}$ is the infiltration rate, $L$ is the distance from the ground surface to the wetting front, $S$ is the matric suction at the wetting front and $K_{S}$ is the saturated conductivity.
In 1973, Main and Larson presented a modified version of the Green-Ampt equation to identify the time at which surface ponding starts in the case of steady rainfall. Chu (1978) extended the applicability of the model under conditions of unsteady rainfall and in this study, a slightly modified version of Chu's approach has been adopted combining it with a water balance at the surface.

The rainfall recorded at the rainfall gauge nearest the site (Pescia) was discretised into a series of one-hour time steps. The infiltration rates and the starting and ending times of ponding conditions were computed at the end of each time step.

The data required for the infiltration analysis includes: the saturated permeability $\left(k_{s}\right)$, the difference between the volumetric water contents before and after wetting $(M=\theta s-\theta i)$ and the matric suction at the wetting-front $(S)$. The mean matric suction measured in the field $(7.2 \mathrm{kPa})$ was considered representative of the initial pore water pressure conditions at the Collodi site and was assumed in the model. The volumetric water content function (characteristic curve) was obtained from the literature for soils with a similar grain size distribution, deriving the saturated water content value $(\theta s)$ from the actual porosity $(n)$ measured in the laboratory.

At the beginning of the storm, the trend of infiltration rate was equal to the rainfall rate, then after the ponding conditions commenced, the infiltration rate reached the maximum value that the soil could sustain, i.e. the infiltration capacity. Since, the storm of 20-21 November 2000 was characterised by a number of high intensity phases, four ponding times were calculated within this period for the Collodi site. Approaching the end of the event, the infiltration rate asymptotically tends towards the saturated permeability $\left(k_{S}\right)$ value (Casagli et al., 2005).

\section{Seepage analysis}

Unsaturated and saturated flow within the slopes were modelled with a finite element seepage analysis using SEEP/W v.4 (Geo-Slope, 2003a) software. The model code is based upon the equations of motion and mass conservation. Both saturated and unsaturated flow are simulated using a modified version of Darcy's law. Darcy's law was originally derived for saturated soils, but later research has shown that it can also be applied to the flow of water through unsaturated soils (Richards, 1931). Under unsaturated conditions the hydraulic conductivity function is no longer a constant but varies with changes in water content (k-curve) (Brooks and Corey, 1964; Fredlund and Rahardjo, 1993) and the governing equation has been extended to incorporate unsaturated conditions (Richards, 1931; Fredlund and Rahardjo, 1993):

$\frac{\partial}{\partial x}\left(k_{x} \frac{\partial H}{\partial x}\right)+\frac{\partial}{\partial y}\left(k_{y} \frac{\partial H}{\partial y}\right)+Q=\frac{\partial \theta}{\partial t}$

Where $H$ is the total head, $K_{x}$ is the hydraulic conductivity in x-direction, $K_{y}$ is the hydraulic conductivity in y-direction, 
$Q$ is the applied boundary flux, $\theta$ is the volumetric water content and $t$ is the time.

Equation (6) states that the difference between the flow entering and leaving an elemental volume at a point in time is equal to the change in the volumetric water content. More fundamentally, it states that the sum of the rates of change of flows in the $\mathrm{x}$ - and $\mathrm{y}$-direction plus the external applied flux is equal to the rate of change of the volumetric water content with respect to time.

The slope section was divided into a mesh of 330 quadrilateral elements (Fig. 3). The results from the infiltration analysis were used as input data for the seepage analysis by assigning the computed infiltration rate versus time function to the ground surface nodes. Zero flux conditions were assigned to the left and lower boundaries. A constant total head of $168 \mathrm{~m}$ was applied to the right vertical boundary, due to the presence of a small creek of fixed water elevation at the toe of the section. An initial matric suction value of $7.2 \mathrm{kPa}$ was used. The hydraulic properties of the materials (characteristic and k-curves) were estimated from the grain-size distribution of the matrix. Finally, the simulation was performed dividing the computed infiltration rate into 34 variable length time steps in order to replicate, as closely as possible, the complexity of the rainfall event.

SEEP/W runs by solving simultaneous equations for each node, thus converging towards a solution. The resulting pore water pressure distributions can then be directly linked into the slope stability analysis, SLOPE/W, which imports the slope mesh previously defined in SEEP/W. This is particularly useful for the current study, since the output from the transient hydrological problem can be used directly in a slope stability model to define the factor of safety with respect to time (Casagli et al., 2005).

\section{Stability analysis}

The slope stability analysis uses, as input data, for each time step the positive and negative pore water pressure distributions obtained from the seepage analysis. SLOPE/W v.4 (Geo-Slope, 2003b), a software that applies limit equilibrium methods, was then used to determine stability with respect to slide type failures. The Morgenstern-Price (1965) method was selected to compute the factor of safety of the soil cover for each of the time steps used in the finite element seepage analysis. In terms of effective stress the Mohr-Coulomb criterion was used for portions of the slope with positive pore water pressures, while the Fredlund et al. (1978) criterion was applied in the case of negative pore water pressures. The failure surface geometry was defined based by GPS measurements after failure and was maintained constant during the entire event.

The shear strength parameters adopted for the analysis are shown in Fig. 3. For each time step of the simulation, the unit weight was updated using:

$\gamma=\gamma_{d}+9.81 \theta$

where $\gamma$ is the unit weight of the soil during the time step, $\gamma_{d}$ is the unit weight of soil under completely dry conditions, and $\theta$ is the volumetric water content during the time step, which is estimated from the soil water characteristic curve using the simulated pore water pressure in that time step.

A function relating $\phi^{b}$ to the matric suction was defined, based on the soil water characteristic curves. This was achieved by dividing the failure envelope into a series of linear segments with varying $\phi^{b}$ angles (from a minimum value of $15^{\circ}$ to a maximum value equal to $\phi^{\prime}$ when the soil approaches saturation) and different intercepts $(c *)$ : each segment corresponding to a range of matric suction (Fredlund and Rahardjo, 1993).

\section{Results}

The time series of the computed factor of safety for the Uzzano, Massa e Cozzile and Collodi landslides are shown in Figs. $4 \mathrm{a}, \mathrm{b}$ and c, respectively. Pore water pressure distribution within the slope at five representative time steps are presented in Fig. 5, while Fig. 6 shows pore water pressure values at four time steps along both the sliding surface (line $\left.\mathrm{A}^{\prime}-\mathrm{A}^{\prime \prime}\right)$ and the vertical $\mathrm{B}^{\prime}-\mathrm{B}^{\prime \prime}$ positioned in the middle of the failure.

The factor of safety trend highlights the influence of soil properties, with reference specifically to the hydraulic conductivity, in controlling the conditions of slope instability. In fact, due to the high permeability of the Collodi soil, at the beginning of the rainfall a quick unsaturated (mean matric suction of about $6 \mathrm{kPa}$ ) downward flux of water forms without the creation of a defined wetting front (see step 2 in Figs. 5 and 6). As a result, factor of safety values remain constant during the first steps of the event (Fig. 4c). During these steps the pore water pressure isolines in the soil layer are almost parallel to the surface and vectors of flow are initially perpendicular to the surface. After the major rainfall peak, the infiltrated water quickly reaches the contact between the soil and the underlying impermeable bedrock, causing a rapid rise in pore water pressures, the formation of a perched water table, and the onset of a downslope flow at the bottom of the colluvium layer. Consequently the factor of safety starts to rapidly decrease, falling to a value less than unity between step 11 (16:30 GMT +1 of 20 November $2000)$ and 12 (19:12 GMT +1 of 20 November 2000), approximately $18 \mathrm{~h}$ after the beginning of the storm (Fig. $4 \mathrm{c}$ ).

At step 11 the distribution of pore water pressures along the profile $\mathrm{B}^{i}-\mathrm{B}^{i i}$ indicates a depth of the water table of $1 \mathrm{~m}$ from the ground surface and a value of matric suction near the ground surface of about $5 \mathrm{kPa}$. At step 12 the distribution of pore water pressures along profile $\mathrm{B}^{i}-\mathrm{B}^{i i}$ shows that the saturated layer increases its thickness and the matric suction 


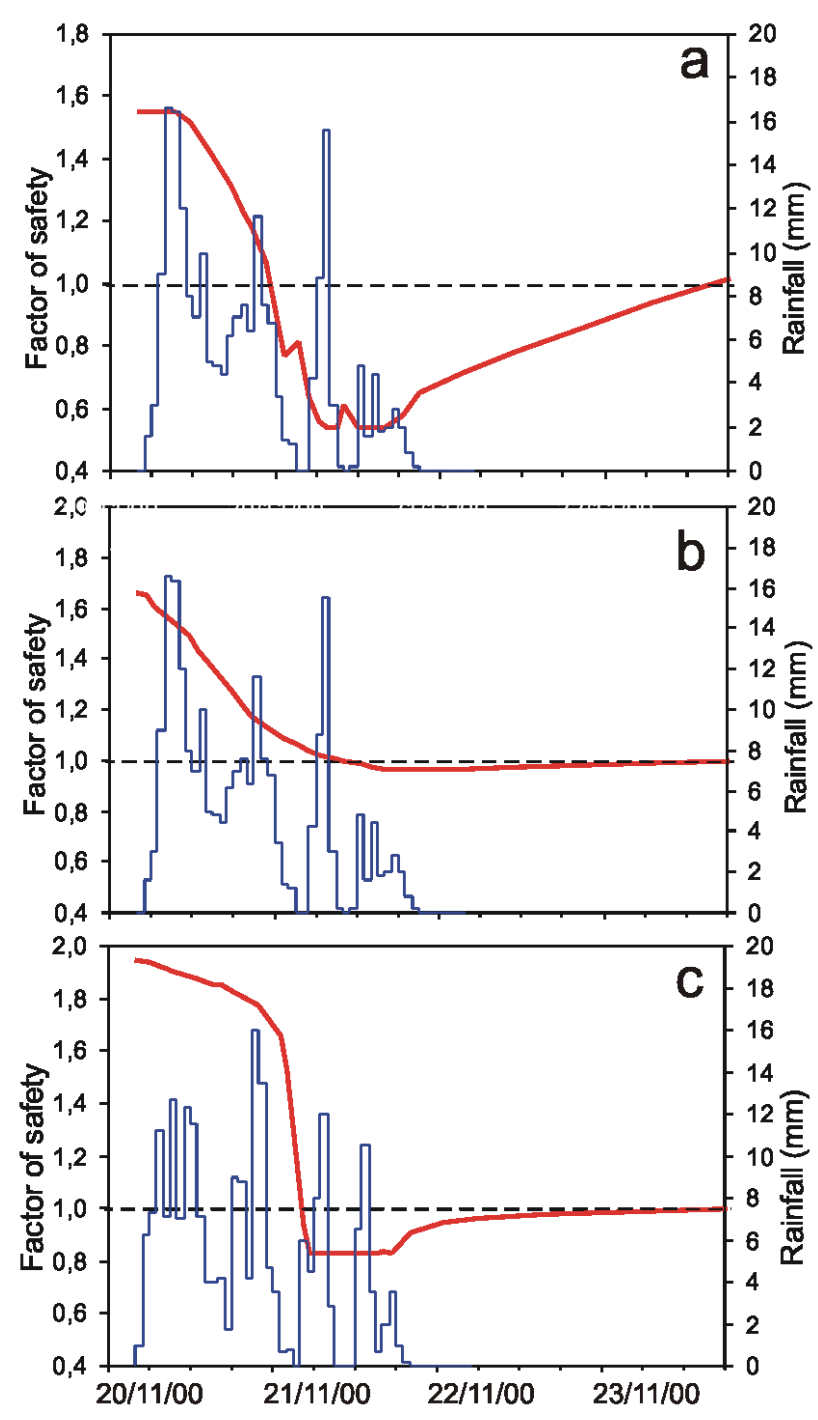

Fig. 4. Trend of factor of safety and rainfall during November 2000 event. (a), Site 3, Collodi. (b), Site 1, Uzzano. (c), Site 2, Massa e Cozzile.

is rapidly decreasing reaching a value of $2 \mathrm{kPa}$ at the ground surface.

The groundwater table continues to rise as a consequence of the prolonged contribution of rainfall water from the slope surface, reaching its maximum elevation at step 21 (08:00 GMT+1 of 21 November 2000) (Figs. 5 and 6) when the factor of safety attains its minimum value (0.54) (Fig. 4c). During this step the soil is completely saturated.

It is also worth noting, the two episodes of rapid increase in the factor of safety between steps 12 and 21, after the two short intervals with no rain, confirming the quick hydraulic response of the high permeability Collodi soil.

At the end of the storm groundwater recession takes place, inducing a rapid decline in pore water pressures, starting from the surface of the slope and leading to a rapid increase

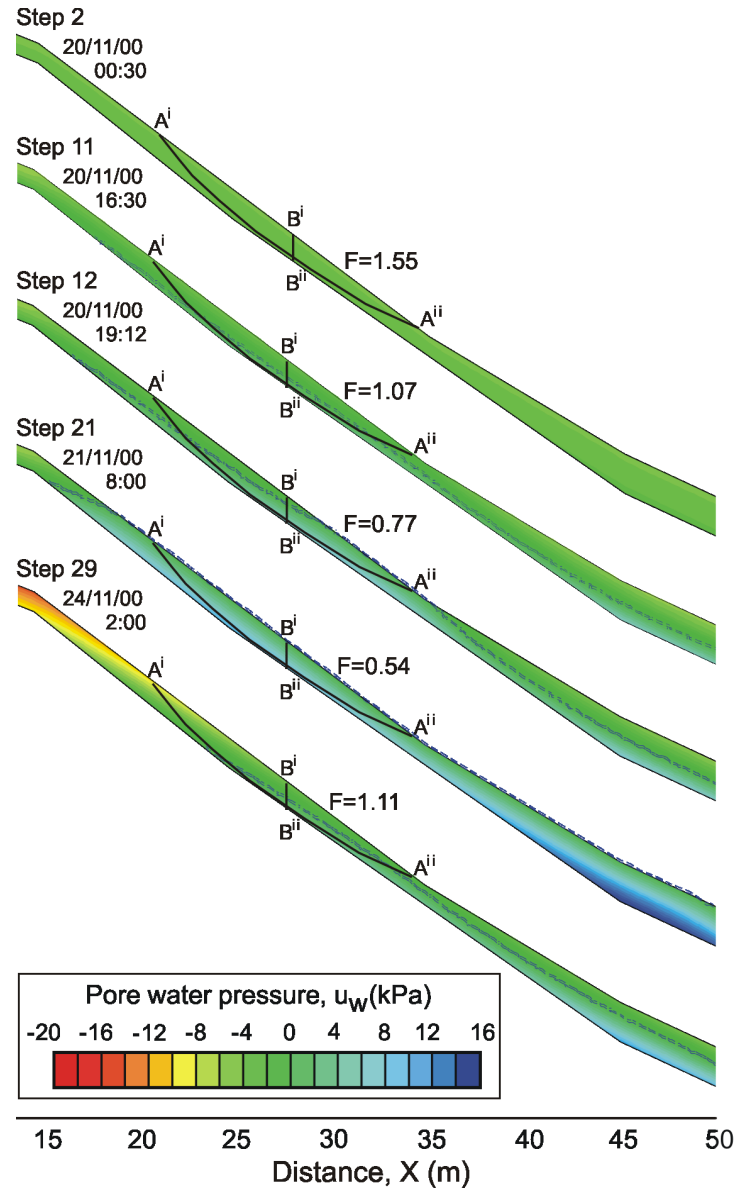

Fig. 5. Results of the seepage and stability analysis: distribution of pore water pressures $\left(u_{w}\right)$ and factor of safety in Site 3 during five different time steps.

of the factor of safety. Stability conditions were reached again between step 28 and step 29 about three-four days after the beginning of the event. At step 29, pore water pressures are positive at the bottom and negative at the top of the soil layer where a rapid desaturation is taking place (Fig. 5).

For comparison Figs. 4a, b show the variation of the factor of safety computed for Uzzano landslide and Massa e Cozzile landslide, described in Casagli et al. (2005). The factor of safety time series computed for the three landslides show that the conditions of instability are reached at 16:30 GMT+1 on 20 November 2000 for the Collodi landslide (Fig. 3c), 06:00 GMT+1 on 21 November 2000 for the Uzzano landslide and 22:30 GMT+1 on 20 November 2000 for the Massa e Cozzile landslide. The different time response of these three sites to the storm is largely dependent upon the different permeability and thickness of the colluvial soil. Uzzano, with the lowest value of permeability and the highest soil depth, presents the slowest response to the storm in terms of instability, whilst, the thinnest and highest permeability Collodi soil layer shows a very rapid response to the storm. 
a

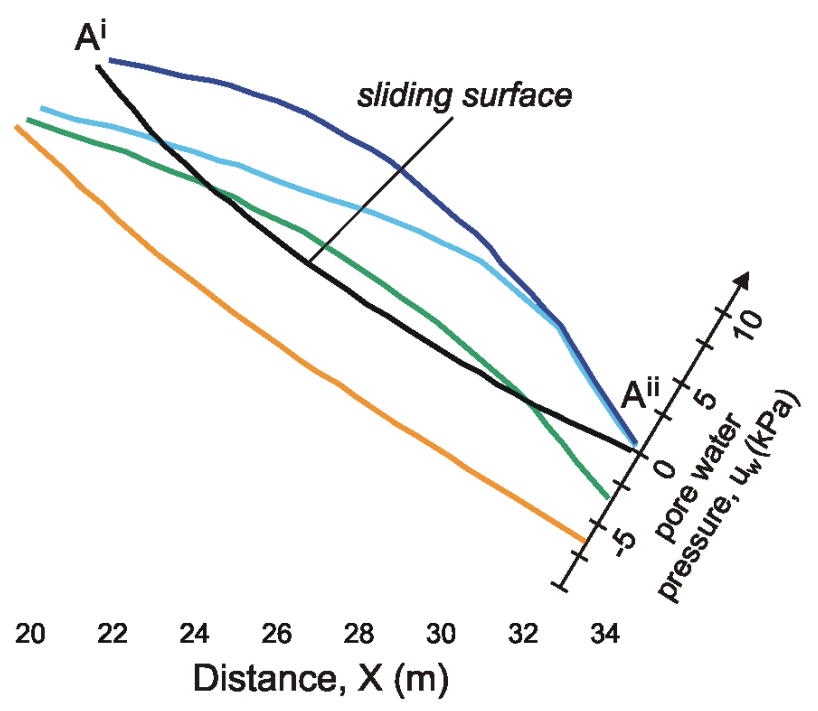

b

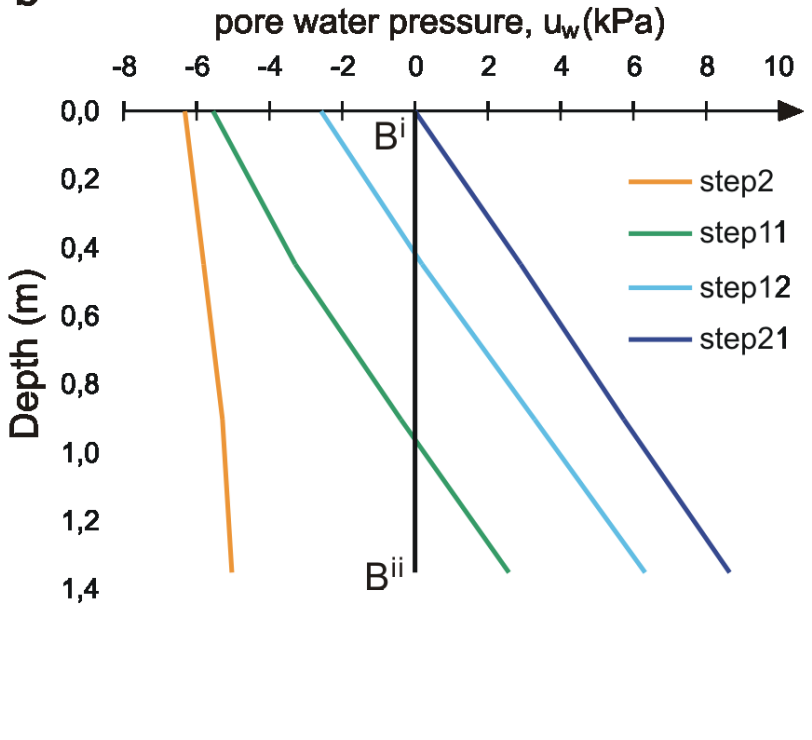

Fig. 6. Positive and negative pore water pressure variations along the sliding surface $\left(\mathrm{A}^{i}-\mathrm{A}^{i i}\right)$ and pore water pressure profile at location $\mathrm{B}^{i}-\mathrm{B}^{i i}$ during four time steps.

\section{Discussion and conclusions}

The results indicate that the simulation of saturated/unsaturated flow within the soil with a finite element seepage analysis, coupled with an infiltration model to determine the actual infiltration rate at the surface, can provide useful insight for the reconstruction of pore water pressure variations, total head and volumetric water content in response to variable intensity rainfall. The assessment of pore water pressure changes at all nodes along the potential failure surface also allows an accurate slope stability analysis to be performed. The trend of the factor of safety indicates that at the Collodi site slope failure occurs about $18 \mathrm{~h}$ after the beginning of the storm, between 04:00 p.m. and 07:00 p.m. on 20 November 2000. The different response between Collodi and the two landslides (Massa e Cozzile and Uzzano) described in previous papers, is a consequence of the different permeability and thickness of the soil layers. In Collodi, higher soil permeability coupled with a shallower depth of the impermeable boundary leads to a very rapid response to the storm, causing the formation of a perched water table only $8 \mathrm{~h}$ after the rainfall initiation and the subsequent trigger of the slope failure.

The detailed soil property characterization performed through a series of in-situ and laboratory tests has provided precise geotechnical parameters as input data for both the hydrological and slope stability models, but at the same time several assumptions were made in the analysis. The depth profile of the contact between the colluvium layer and the bedrock was based on limited data. In addition, the bedrock was considered impermeable, thereby preventing the flow through this interface. The soil characteristics and k-curves along with the initial pore water pressure conditions were derived from literature data integrated with the measured parameters of soil porosity, saturated permeability and mean matric suctions.

Moreover, the infiltration model and the seepage analysis are based on assumptions and have various limitations. In the seepage analysis, the computed infiltration rate is assigned to the nodes along the ground surface as a boundary condition, thus not considering the contribution of the upslope runoff and probably causing an underestimation of pore water pressures.

Further development of this research would be useful. In order to progress the modelling of landslide triggering mechanisms during a rainfall event the following objectives, recently defined in Casagli et al. (2005), need to be considered:

- to calibrate the model with real-time pore-water pressure measurements taken during a similar event;

- to determine a more detailed description of the morphology and hydraulic properties at the transition between the colluvium and the bedrock;

- to evaluate the hydrological and mechanical effects of the covering vegetation.

Acknowledgements. The research was conducted within the Earth Sciences Department of Florence University and funded by GNDCI, and the authors would like to mention, in particular, P. Canuti, for his supervision during the research, M. L. Ibsen 
for her comments and suggestions on the paper and G. Falorni, M. Mirannalti and G. Villani for their assistance with the fieldwork.

Edited by: F. Guzzetti

Reviewed by: R. Guthrie and another referee

\section{References}

Affuso, A. M., Casagli, N., Dapporto, S., Gabbani, G., Gargini, A., and Rinaldi, M.: Monitoring and modelling of unsaturated flow and effects on streambank failures,in: Landslides research, theory and practice, edited by: Bromhead, E., Dixon, N., and Ibsen, M. L., Proc. of eighth international symposium on landslides, 26-30 June 2000, Cardiff, 2000.

Aleotti, P., Polloni, G., Casagli, N., and Dapporto, S.: Shallow failures triggered by the November 2002 meteoric event in the Albaredo Valley, Valtellina (Italian Central Alps): mechenics and stability analyses, in: Landslides, Evaluation and Stabilization, edited by: Lacerba, W. A., Ehrlich, M., Fontoura, S. A. B., and Sayão, A. S. F., Proc. Of the ninth international symposium on landslides, 28 June, 2 July, 2004, Rio de Janeiro, 2004.

Amoozegar, A.: Compact constant head permeameter for measuring saturated hydraulic conductivity of the vadose zone, Soil Sci. Soc. Amer. J., 53, 1356-1361, 1989.

Anderson, M. G. and Lloyd, D. M.: Using a combined slope hydrology/stability model to develop cut slope design charts, Proc. Inst. Civil Engineers, 91(2), 705-718, 1991.

Anderson, M. G. and Howes, S.: Development and application of a combined soil water-slope stability model, Quart. J. Eng. Geology, 18, 225-236, 1985.

Bronstert, A.: Modellierung der Abflussbildung und der Bodenwasserdynamik von Hangen, Universitat Karlsruhe, 46 pp, 1994.

Brooks, R. H., Corey, A. T.: Hydraulic properties of porous media, Hydrol. Paper No. 3, Colorado State University, Ft. Collins, Co, 1964.

Brooks, S. M. and Richards, K. S.: The significance of rainstorm variations to shallow translational hillslope failure, Earth Surface processes and landforms, 19(1), 85-94, 1994.

Caine, N.: The rainfall intensity-duration control of shallow landslides and debris-flows, Geografiska Annaler, 62A, 23-27, 1980.

Cannon, S. H. and Ellen, S. D.: Rainfall that resulted in abundant debris-flows activity during the storm, in: Landslides floods and marine effects of the storm of January 3-5, 1982, in the San Francisco Bay region, California, edited by: Ellen, S. D. and Wieczorek, G. F., U.S. Geological Survey Professional Paper, 1434, 27-33, 1988.

Casagli, N., Dapporto, D., Ibsen, M. L., Tofani, V., and Vannocci, P.: Analysis of triggering mechanism during the storm of 20-21 Novembre 2000, in northern Tuscany, Landslides, 3(1), 13-21, 2005.

Chu, S. T.: Infiltration during an unsteady rain, Water Resour. Res., 14, 461-466, 1978.

Collins, B. D. and Znidarcic, D.: Stability analyses of rainfall induced landslides, J. Geotechnical Geoenvironmental Eng., 130, 362-372, 2004.

Corominas, J.: Landslides and Climate, Keynote Lectures from the 8th International Symposium on Landslides, No 4, pp 1-33, 2001.
Crosta, G.: Regionalization of rainfall thresholds: an aid to landslide hazard evaluation, Environmental Geology, 35, 2-3, 1998.

Crosta, G. B. and Dal Negro, P.: Observations and modelling of soil slip-debris flow initiation processes in pyroclastic deposits: the Sarno 1998 event, Nat. Hazards Earth Syst. Sci., 3, 53-69, 2003, http://www.nat-hazards-earth-syst-sci.net/3/53/2003/.

Crozier, M. J.: Landslides: Causes, Consequences and Envirorment, Croom Helm, London, pp. 252, 1986.

Cruden, D. M. and Varnes, D. J.: Landslide types and processes, in: Landslides Investigation and Mitigation, edited by: Turner, A. K. and Schuster, R. L., special report 247, National Academy Press, Washington D.C., 1996.

Dapporto, S., Focardi, P., and Vannocci, P.: La parametrizzazione geotecnica di un materiale non saturo mediante prove in sito, Geologia Tecnica Ambientale, 3, 5-11, 2000.

Fredlund, D. G., Morgenstern, N. R., and Widger, R. A.: The shear strength of unsaturated soils, Can. Geotechnical J., 15, 312-321, 1978.

Fredlund, D. G. and Rahardjo, H.: Soil Mechanics for Unsaturated Soils, New York, John Wiley \& Sons, 1993.

Geo-Slope: SEEP/W model and User manual 2000, Geo-Slope International, 2003a.

Geo-Slope: SLOPE/W model and User manual 2000, Geo-Slope International, 2003b.

Glade, T., Crozier, M., and Smith, P.: Applying Probability Determination to Refine Landslide-triggering Rainfall Thresholds Using an Empirical “Antecedent Daily Rainfall Model”, Pure Appl. Geophys., 157, 1059-1079, 2000.

Govi, M. and Sorzana, P. F.: Landslides susceptibility as a function of critical rainfall amount in Piedmont Basins, Studia Geomorphologica Carpatho-Balcanica, 14, 43-61, 1980.

Green, W. H. and Ampt, G. A.: Studies on soil physics: 1. Flow of air and water through soils, J. Agric. Sci., 4, 1-24, 1911.

Jakob, M. and Weatherly, H.: A hydroclimatic threshold for landslide initiation on the North Shore Mountains of Vancouver, British Columbia, Geomorphology, 54, 137-156, 2003.

Johnson, K. A. and Sitar, N.: Hydrologic conditions leading to debris-flow initiations, Can. Geotechnical J., 27, 789-801, 1990.

Kim, S. K., Hong, W. P., and Kim, Y. M.: Prediction of rainfalltriggered landslides in Korea, in: Proceedings of the 6th International Symposium on Landslides, edited by: Bell, D. H., Christchurch, New Zealand, Balkema, Rotterdam, pp. 989-994, 1991.

Ko Ko, C., Flentje, P., and Chowdhury, R.: Interpretation of probability of landsliding triggered by rainfall, Landslides, 1, 263275, 2004.

Iverson, R. M.: Landslide triggering by rainfall infiltration, Water Resour. Res., 36, 1987-1910, 2000.

Lutenegger, A. J. and Halberg, G. R.: Borehole Shear Test in geotechnical investigation. Special Technical Publ. American Society for Testing and Materials, 740, 566-578, 1981.

Mein, R. G. and Larson, C. L.: Modeling the infiltration component of the rainfall-runoff process, Bull. 43, Water Resour. Res. Center of Minn., Minneapolis, 1973.

Morgenstern, N. R. and Price, V. E.: The analysis of the stability of general slip surfaces, Geotechnique, 15, 79-93, 1965.

Pasuto, A. and Silvano, S.: Rainfall as a trigger of shallow mass movements. A case of study in the Dolomites, Italy, Environ. Geology, 35(2-3), 184-189, 1998. 
Richards, L. A.: Capillary conduction of liquids through porous mediums, Physics, 1, 318-333, 1931.

Rinaldi, M., Casagli, N., Dapporto, S., and Gargini, A.: Monitoring and modelling of pore water pressure changes and riverbank stability during flow events, Earth Surf. Processes and Landforms, 29, 237-254, 2004.

Sanderson, F., Bakkehøi, S., Hestenes, E., and Lied, K.: The influence of meteorological factors on the initiation of debris flows, rockfalls, rockslides and rockmass stability, in: Landslides. Proceedings 7 th International Symposium on Landslides, edited by: Senneset, K., A.A. Balkema, 1, 1996.

Sidle, R. C. and Dhakal, A. S.: Potential effects of environmental change on landslide hazards in forest environments, in: Environmental Change and Geomorphic Hazards in Forests, edited by: Sidle, R. C., IUFRO Research Series, No. 9, pp. 123-165, CAB International Press, Oxen, UK, 2002.

Terlien, M. T. J.: Modelling spatial and temporal variations in rainfall-triggered landslides. ITC Publ. 32, Enschede, Netherlands, 50 pp, 1996.

Terlien, M. T. J.: The determination of statistical and deterministic hydrological landslide-triggering thresholds, Environ. Geology, 35, 2-3, 1998.
Tofani, V.: Analisi dei meccanismi di innesco dei fenomeni franosi del Novembre 2000 in provincia di Pistoia, Master thesis, 2003.

Van Asch, T. W. J., Buma, J., and Van Beek, L. P. H.: A view on some hydrological triggering systems in landslides, Geomorphology, 30, 25-32, 1999.

Van Genuchten, M. T.: A closed-form equation for predicting the hydraulic conductivity of unsaturated soils, Soil Sci. Soc. Amer. J., 48, 703-708, 1980.

Wagner, A. A.: The use of the Unified Soil Classification System by the Bureau of Reclamation. Proc. 4th International Conference on Soil Mechanics and Foundation Engineering, I, 125, London, 1957.

Wieczorek, G. F.: Effect of rainfall intensity and duration on debris flows in central Santa Cruz Mountains, California, Geolog. Soc. Amer., Reviews in Engineering Geology, 7, 1987.

Wieczorek, G. F.: Landslide triggering mechanisms, in: Landslides Investigation and Mitigation, edited by: Turner, A. K. and Schuster, R. L., special report 247, National Academy Press, Washington D.C., 1996. 